\title{
MicroRNA-126a-5p enhances myocardial ischemia-reperfusion injury through suppressing Hspb8 expression
}

\author{
Bimei Jiang ${ }^{1}$, Yanjuan Liu ${ }^{1}$, Pengfei Liang ${ }^{2}$, Yuanbin Li ${ }^{1}$, Zhenguo Liu ${ }^{3}$, Zhongyi \\ Tong $^{1}$, Qinglan Lv ${ }^{1}$, Meidong Liu ${ }^{1}$ and Xianzhong Xiao ${ }^{1}$ \\ ${ }^{1}$ Department of Pathophysiology, Xiangya School of Medicine, Central South University, Changsha, P. R. China \\ ${ }^{2}$ Department of Burns and Plastic Surgery, Xiangya Hospital, Central South University, Changsha, P. R. China \\ ${ }^{3}$ Dorothy M. Davis Heart and Lung Research Institute, Division of Cardiovascular Medicine, Department of Internal Medicine, \\ The Ohio State University Wexner Medical Center, Columbus, OH, USA
}

Correspondence to: Xianzhong Xiao, email: xiaoxianzhong@csu.edu.cn

Keywords: microRNA-126a-5p; myocardium; ischemia-reperfusion injury; Hspb8; H9C2 cells

Received: April 19, $2017 \quad$ Accepted: August 23, $2017 \quad$ Published: October 07, 2017

Copyright: Jiang et al. This is an open-access article distributed under the terms of the Creative Commons Attribution License 3.0 (CC BY 3.0), which permits unrestricted use, distribution, and reproduction in any medium, provided the original author and source are credited.

\section{ABSTRACT}

Previously, we found several genes are involved in myocardial ischemiareperfusion (M-I/R) injury. In this report, we first developed a mouse model of $M-I / R$ injury and demonstrated microRNA-126a-5p was associated with the M-I/R injury by using high-throughput microRNA expression analysis. We further investigated the expression and function of microRNA-126a-5p during mouse M-I/R injury. We observed high expression of microRNA-126a-5p in the M-I/R mice and increased levels of LDH and CK-MB (damage markers) in the serum. $\mathrm{H}_{2} \mathrm{O}_{2}$ and hypoxia/reoxygenation $(H / R)$ treatment significantly increased the expression of microRNA-126a-5p in H9C2 cells in concentration- and time-dependent manners. Moreover, microRNA-126a5 p overexpression in $\mathrm{H} 9 \mathrm{C} 2$ cells inhibited cell viability but increased LDH release and caspase 3 activity. Cardiac function analysis based on the measurements of hemodynamic parameters showed that microRNA-126a-5p expression ablation in $M-I / R$ injured mice led to the reversal of the symptoms caused by M-I/R injury. Transesophageal echocardiography also revealed that the values of LVIDd and LVIDs were decreased while the values of LVFS\% and LVEF\% were increased in M-I/R injured mice after treatment with microRNA-126a-5p inhibitor, compared with the $M-I / R$ injured mice treated with the control. Bioinformatic analysis demonstrated that Hspb8, a protective protein in myocardium, was the target of microRNA-126a-5p. Thus, these findings indicated that microRNA-126a-5p was up-regulated in mouse $M-I / R$ model and promoted $M-I / R$ injury in vivo through suppressing the expression of Hspb8, which may shed light on the development of potential therapeutic target for M-I/R injury.

\section{INTRODUCTION}

Ischemic heart disease (IHD) contributes to the development of cardiovascular disease, which in turn leads to patient death. The current IHD treatment involves reperfusion of the blocked artery, but reperfusion may lead to myocardial ischemia-reperfusion (M-I/R) injury, including myocardial stunning, cardiomyocyte death, microvascular obstruction and arrhythmias [1]. Therefore, it is important to figure out potential protective mechanisms for myocardial I/R-induced injury.

MicroRNAs are a kind of endogenous, single-stranded RNAs about 18-20 nucleotides, which can regulate gene expression by targeting 3 '-end untranslated region (UTR) of mRNAs at posttranscriptional level. It has been speculated that more than $60 \%$ of human genes are regulated by 
microRNAs [2-4]. Number of studies have reported the involvement of microRNAs in the regulation of multiple important physiological and pathological processes [5-7], including cell proliferation, migration and apoptosis. Some microRNAs such as microRNA-320, microRNA-103/107, microRNA-141 and microRNA-21 have specifically been implicated to play an important role in the cardiac development and myocardial I/R injury [8-12].

Among various microRNAs, microRNA-126a-5p is abundantly expressed in the endothelial cells and tissues with lots of vessels, such as lung, liver, and heart [13]. Its association with coronary heart disease, heart failure and atherosclerosis has been reported $[14,15]$. However, there is no study about the relationship between microRNA$126 a-5 p$ expression and M-I/R injury. Therefore, in this study, we performed a comparative microRNA profiling to identify the differentially expressed miRNAs in mouse $\mathrm{M}-\mathrm{I} / \mathrm{R}$ injury model and identified microRNA-126a-5p as a promising candidate. Further investigation showed that microRNA-126a-5p was up-regulated in mouse $\mathrm{M}-\mathrm{I} / \mathrm{R}$ model and promoted $\mathrm{M}-\mathrm{I} / \mathrm{R}$ injury in vivo through suppressing the expression of Hspb8, a protective protein in cardiomyocytes. These findings provide strong insights for developing a new therapeutic strategy for $M-I / R$ injury.

\section{RESULTS}

\section{Analysis of microRNA-126a-5p expression during $M-I / R$ injury}

To study the expression profile of microRNAs during $\mathrm{M}-\mathrm{I} / \mathrm{R}$ injury, a $\mathrm{M}-\mathrm{I} / \mathrm{R}$ injury mouse model was established. As shown in Figure 1, we found myocardial fibers were disorderly arranged and dissolved, along with being infiltrated by the inflammatory cells (Figure 1A). Moreover, the mice from M-I/R group displayed higher serum levels of LDH and CK-MB than the sham group, especially $4 \mathrm{hrs}$ after reperfusion $(P<0.01)$ (Figure 1B). These results suggest the M-I/R injury mouse model was established successfully. Then, a miRNA microarray assay was performed in the myocardial tissues harvested at $12 \mathrm{~h}$ after reperfusion. According to the dramatical changes in the heat-map results, microRNA-126a-5p was one of the top upregulated microRNAs in all samples (Figure 1C). To verify the results of microarray, qPCR results further confirmed that microRNA-126a-5p was significantly upregulated at the $6 \mathrm{~h}$ after reperfusion and reached to the peak at $12 \mathrm{hrs}$ after reperfusion (Figure 1D). These data suggest that the elevated expression of microRNA-126a$5 \mathrm{p}$ may play important roles in M-I/R injury.

\section{The role of microNA-126a-5p in $\mathrm{H} 9 \mathrm{C} 2$ cells injury induced by $\mathrm{H}_{2} \mathrm{O}_{2}$ or $\mathrm{H} / \mathrm{R}$}

To further examine the in vitro expression of microRNA-126a-5p, H9C2 cells were treated with various concentrations of $\mathrm{H}_{2} \mathrm{O}_{2}$ for different time points to induce cell damage, then the expression of microRNA$126 \mathrm{a}-5 \mathrm{p}$ was assessed by RT-QPCR. As shown in Figure $2, \mathrm{H}_{2} \mathrm{O}_{2}$ treatment increased the expression of microRNA-126a-5p in $\mathrm{H} 9 \mathrm{C} 2$ cells and $0.5 \mathrm{mmol} / \mathrm{L}$ of $\mathrm{H}_{2} \mathrm{O}_{2}$ treatment for $24 \mathrm{hrs}$ showed the maximum effect. Moreover, the increase in microRNA-126a-5p expression by $\mathrm{H}_{2} \mathrm{O}_{2}$ treatment was time-dependent (Figure 2A, 2B). Further, the $\mathrm{H} 9 \mathrm{C} 2$ cells were treated with $\mathrm{Na}_{2} \mathrm{~S}_{2} \mathrm{O}_{4}$ $(4 \mathrm{mM})$ to induce hypoxia/reoxygenation $(\mathrm{H} / \mathrm{R})$ injury. As shown in Figure 2C, compared to the control group, H/R injury (hypoxia for 1, 2, 4, $8 \mathrm{~h}$ and reoxygenation 12 h) increased the expression of microRNA-126a-5p, and hypoxia $4 \mathrm{~h}$ and reoxygenation $12 \mathrm{~h}$ treatment showed the maximum effect.

To further study the role of elevated microRNA126a-5p in $\mathrm{H} 9 \mathrm{C} 2$ cell injury induced by $\mathrm{H}_{2} \mathrm{O}_{2}$ or $\mathrm{H} / \mathrm{R}$, we used its mimic and inhibitor to regulate its expression. MicroRNA-126a-5p mimic enhanced its expression in $\mathrm{H} 9 \mathrm{C} 2$ cells compared with the control and mimic-negative transfected cells (Figure 3A). Conversely, the cells transfected with microRNA126a-5p inhibitor showed less expression compared to control and inhibitor negative transfection $(P<0.05)$ (Figure 3A). We further treated above transfected $\mathrm{H} 9 \mathrm{C} 2$ cells with $0.5 \mathrm{mmol} / \mathrm{L} \mathrm{H}_{2} \mathrm{O}_{2}$ for $24 \mathrm{hrs}$, then cell viability, LDH level and caspase 3 activities in the supernatant were analyzed. Cell viability was robustly decreased after $\mathrm{H}_{2} \mathrm{O}_{2}$ treatment. After being transfected with microRNA-126a-5p mimic, cell viability was further decreased. While microRNA-126a-5p inhibitor significantly rescued $\mathrm{H}_{2} \mathrm{O}_{2}$-induced decrease in cell viability in $\mathrm{H} 9 \mathrm{C} 2$ cells $(P<0.05)$ (Figure $3 \mathrm{~B})$. LDH level and caspase 3 activity were significantly increased following $\mathrm{H}_{2} \mathrm{O}_{2}$ exposure and further enhanced in the cells transfected with microRNA-126a-5p mimic, but $\mathrm{H}_{2} \mathrm{O}_{2}$-induced increase in LDH level and caspase 3 activity was reversed by microRNA-126a-5p inhibitor (Figure 3C and 3D). Additionally, two control groups (mimic-negative group and inhibitor-negative group) did not show any significant differences in all parameters compared with $\mathrm{H}_{2} \mathrm{O}_{2}$ group $(P>0.05)$ (Figure 3B-3D). Also, the viability assay revealed that $\mathrm{Na}_{2} \mathrm{~S}_{2} \mathrm{O}_{4}$-induced hypoxia/reoxygenation decreased cell viability. As shown in Figure 3E, the viability of the cells exposed to $\mathrm{Na}_{2} \mathrm{~S}_{2} \mathrm{O}_{4}$ at concentrations of $4 \mathrm{mM}$ for $4 \mathrm{~h}$ and replacing the normal medium for an additional $12 \mathrm{~h}$ significantly decreased to $63.11 \pm 7.13 \%$ of the control value $(\mathrm{n}=6, \mathrm{P}<0.01)$. Compared to the model group, pretreatment with microRNA-126a-5p mimic, cell viability was further decreased. While pretreatment with microRNA-126a-5p inhibitor significantly attenuate hypoxia/reoxygenation-induced decrease in cell viability in $\mathrm{H} 9 \mathrm{C} 2$ cells $(\mathrm{P}<0.05)$. These data demonstrate that microRNA-126a-5p enhance H9C2 cells injury induced by $\mathrm{H}_{2} \mathrm{O}_{2}$ or $\mathrm{H} / \mathrm{R}$. 


\section{Effect of microRNA-126a-5p ablation on $M-I / R$ injury in vivo}

To further study the role of microRNA-126a-5p in I/R injury, we analyzed the effect of microRNA-126a$5 p$ ablation on the $\mathrm{M}-\mathrm{I} / \mathrm{R}$ injury in mice. As shown in Figure 4 , the inhibitory effect of microRNA-126a-5p inhibitor (LNA-miR-126a-5p) was obvious as early as 6 hrs after injection, in which the expression of microRNA- 126a-5p was decreased by $38.53 \%$. The expression of microRNA-126a-5p by its inhibitor was inhibited in a time-dependent manner, suggesting that microRNA126a-5p inhibitor (LNA-miR-126a-5p) is potent and can inhibit the expression of microRNA-126a-5p effectively in mice $(P<0.01)$ (Figure 4A). We also tested this inhibitor in $\mathrm{M}-\mathrm{I} / \mathrm{R}$ injury mouse model and found that tail vein injection of microRNA-126a-5p inhibitor inhibited the up-regulation of microRNA-126a-5p expression in M-I/R

A

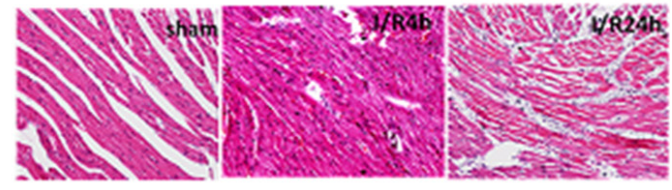

B

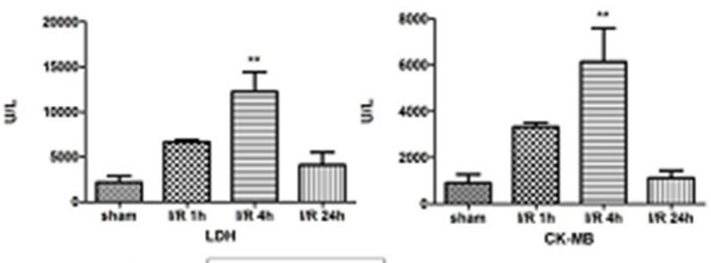

c
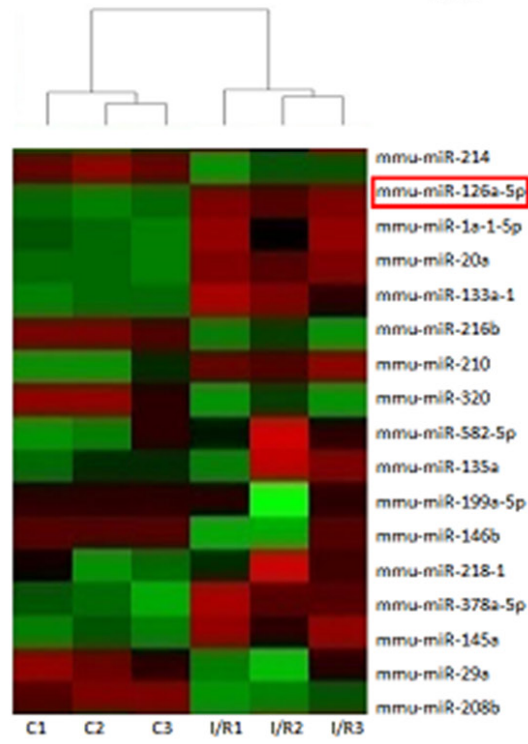

D

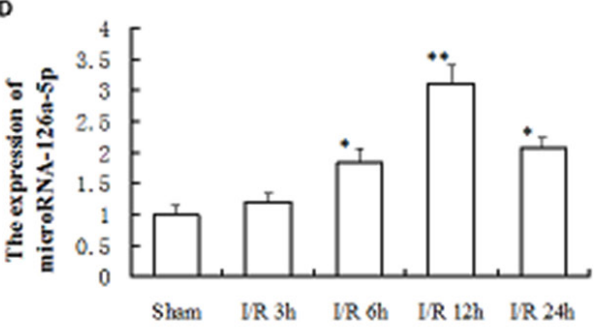

Figure 1: Analysis of microRNA-126a-5p expression during myocardial ischemia reperfusion injury. (A) HE staining displaying the change in myocardial tissue morphology. sham: sham group, I/R: ischemia reperfusion injury. (B) Detection of LDH and CK-MB levels in serum to assess myocardial damage. LDH: lactate dehydrogenase; CK-MB, creatine kinase-MB. ${ }^{* *}, P<0.01, v s$. sham group, $\mathrm{n}=6$. (C) Heatmap of microarray result. (Simplified version). Red color represents up-regulation while green color represents downregulation. (D) RT-QPCR analysis of the microRNA-126a-5p expression in the myocardium from sham and ischemia reperfusion injury mice. ${ }^{*}, P<0.05$, vs. sham group; ${ }^{* *}, P<0.01$, vs. sham group, $\mathrm{n}=6$. 
injury mouse model $(P<0.01)$, while injection of control inhibitor (LNA-Scr) did not show any effect (Figure 4B). Moreover, the increased levels/expression of CK levels in serum (Figure 4C) and caspase-3 activity (Figure 4D) were inhibited by microRNA-126a-5p inhibitor in M-I/R injury mice. These results indicate that microRNA-126a$5 \mathrm{p}$ inhibitor can attenuate the cardiac injury.

\section{Effect of microRNA-126a-5p ablation on cardiac hemodynamic measurement}

The cardiac functions of the mice underwent $\mathrm{I} / \mathrm{R}$ injury were assessed by measuring hemodynamic parameters. I/R injury markedly increased the LVEDP (left ventricular end-diastolic pressure) but significantly

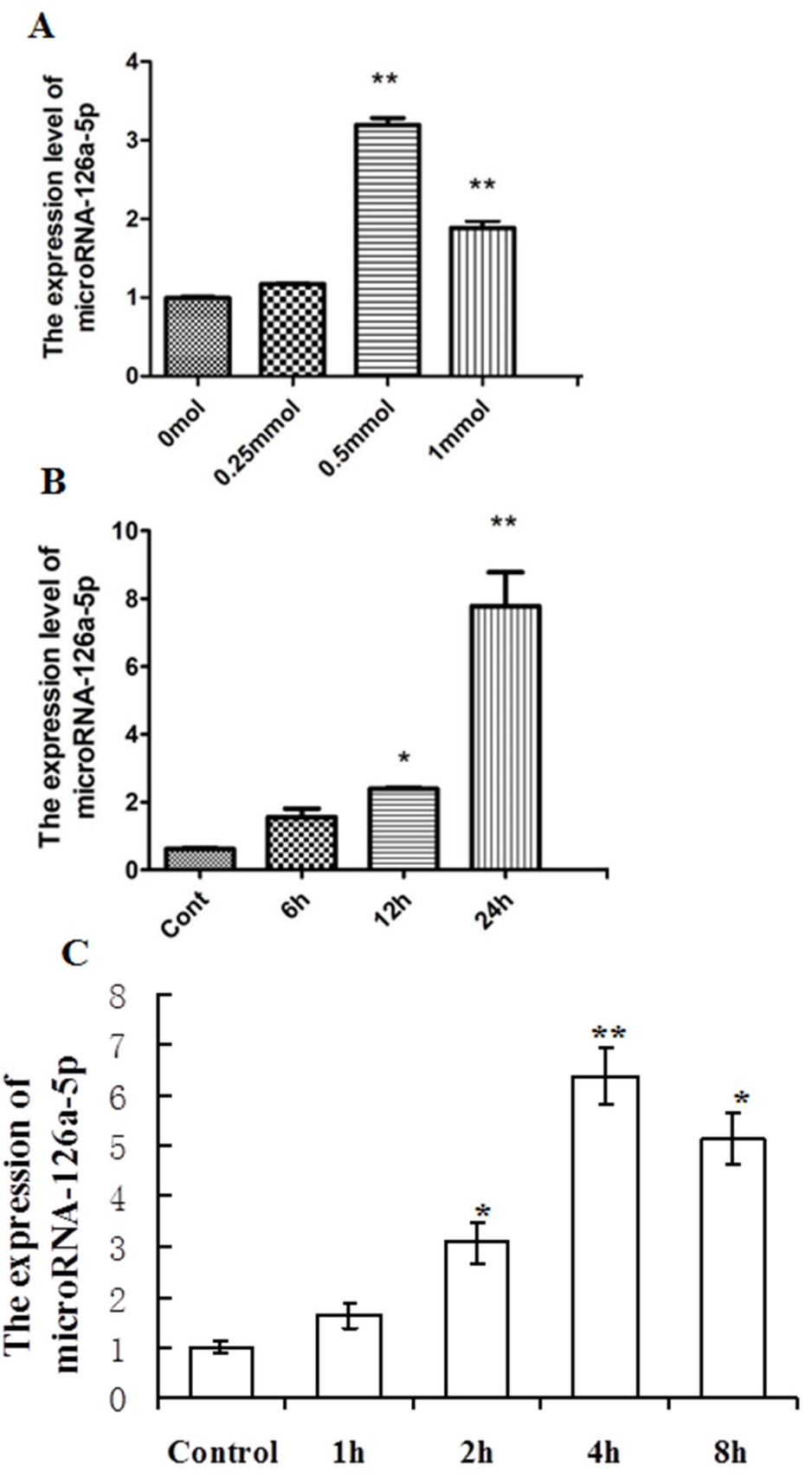

Figure 2: Analysis of microRNA-126a-5p expression in $\mathrm{H} 9 \mathrm{C} 2$ cardiomyocytes injury mediated by $\mathrm{H}_{2} \mathrm{O}_{2}$ or hypoxia/ reoxygenation $(\mathbf{H} / \mathbf{R})$. (A) $\mathrm{H} 9 \mathrm{C} 2$ cells treated with $\mathrm{H}_{2} \mathrm{O}_{2}$ at different concentrations, $0 \mathrm{mmol} / \mathrm{L}, 0.25 \mathrm{mmol} / \mathrm{L}, 0.5 \mathrm{mmol} / \mathrm{L}, 1 \mathrm{mmol} / \mathrm{L}$ for $24 \mathrm{hrs}$, microRNA-126a-5p expression was analyzed by RT-QPCR. ${ }^{* *}, P<0.01, v s .0$ mmol group, $\mathrm{n}=6$. (B) H9C2 cells treated with 0.5 $\mathrm{mmol} / \mathrm{L} \mathrm{H}_{2} \mathrm{O}_{2}$ for $0 \mathrm{~h}, 6 \mathrm{~h}, 12 \mathrm{~h}, 24 \mathrm{~h}$, and microRNA-126a-5p expression was assessed by RT-QPCR. ${ }^{*}, P<0.05$ vs. control group, $\mathrm{n}=8,{ }^{* *}, P$ $<0.01$ vs. 0h group, $\mathrm{n}=8$. (C) After $\mathrm{H} 9 \mathrm{C} 2$ cells were exposed to $1 \mathrm{~h}, 2 \mathrm{~h}, 4 \mathrm{~h}, 8 \mathrm{~h}$ of $\mathrm{Na}_{2} \mathrm{~S}_{2} \mathrm{O}_{4}$ and then to $12 \mathrm{~h}$ of reoxygenation, microRNA$126 \mathrm{a}-5 \mathrm{p}$ expression was analyzed by RT-QPCR. ${ }^{*}, \mathrm{P}<0.05$ vs. control group; ${ }^{* *}, \mathrm{P}<0.01$ vs. control group, $\mathrm{n}=6$. 
decreased the LVSP (left ventricular systolic pressure) compared to the mice in the sham group. Moreover, the $+\mathrm{dp} /$ $\mathrm{dt}_{\max }$ (the maximum rate of left ventricular pressure rise) was significantly higher in $\mathrm{I} / \mathrm{R}$ injury mice, but $-\mathrm{dp} / \mathrm{dt}_{\text {max }}$ (the maximum rate of left ventricular pressure decline) was lower than that in the sham group. Interestingly, inhibition of microRNA-126a-5p by its inhibitor showed significant reversal of these parameters (i.e. higher LVSP and markedly lower LVEDP compared with I/R group). The $+\mathrm{dp} / \mathrm{dt}_{\text {max }}$ and $-\mathrm{dp} / \mathrm{dt}_{\max }$ values were also reversed by the microRNA126a-5p inhibitor (Figure 5). Additionally, the injection of scramble inhibitor showed no significant effect on I/Rinduced effects on the hemodynamic parameters. Also, no significant difference in the heart rate was observed in
A

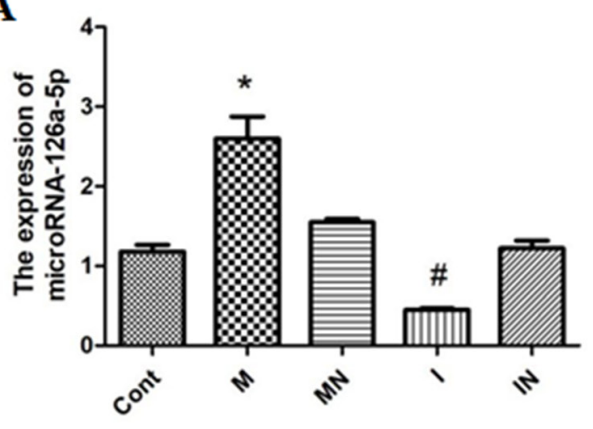

C

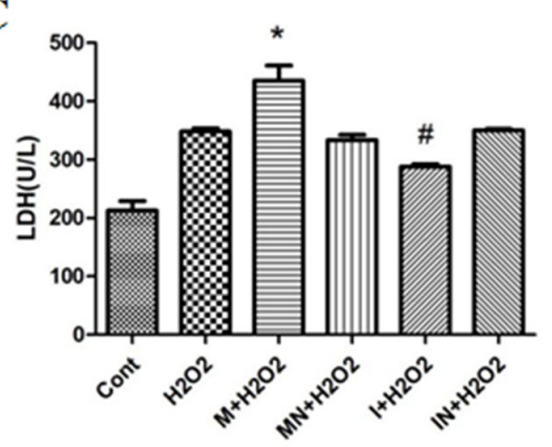

B

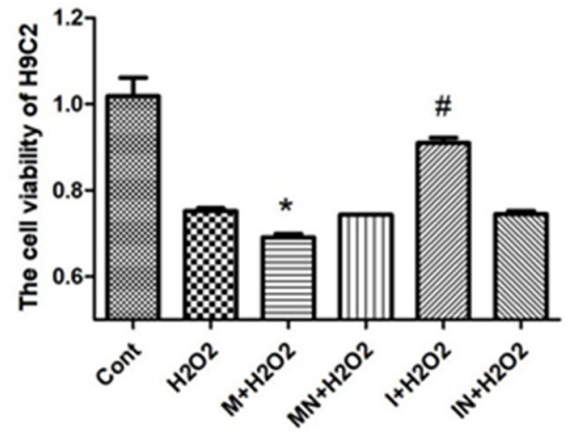

D

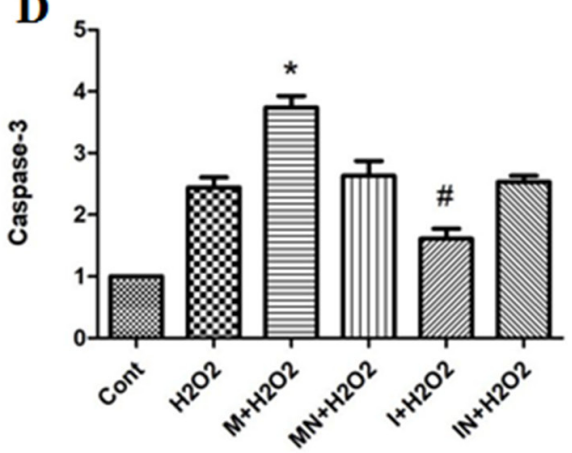

$\mathbf{E}$

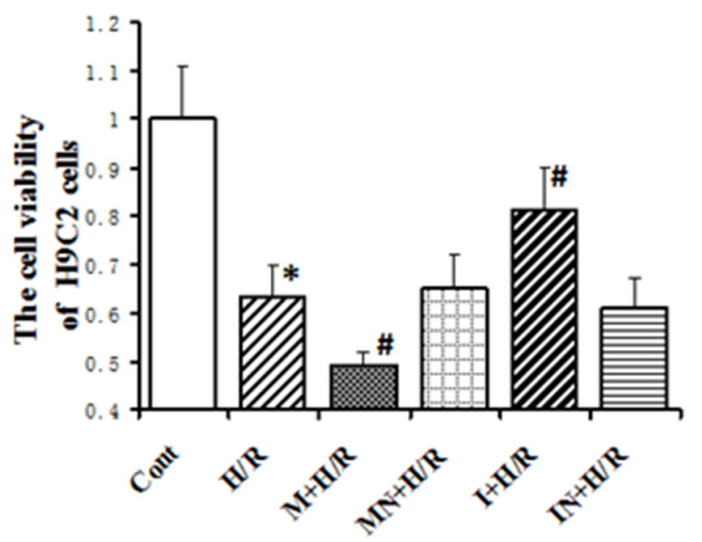

Figure 3: The role of microRNA-126a-5p in $\mathbf{H} 9 \mathrm{C} 2$ cells injury mediated by $\mathrm{H}_{2} \mathrm{O}_{2}$ or $\mathbf{H} / \mathrm{R}$. (A) RT-QPCR detected the expression of microRNA-126a-5p in H9C2 cells transfected with microRNA-126a-5p mimic or inhibitor. ${ }^{*}, P<0.05$, vs. control group, $\mathrm{n}=6$; ${ }^{*}, P<0.05$, vs. control group, $\mathrm{n}=6$. (B) Analysis ofcell viability of $\mathrm{H} 9 \mathrm{C} 2$ cardiomyocytes treated with $\mathrm{H}_{2} \mathrm{O}_{2}$ after microRNA-126a-5p mimic or inhibitor transfection. ${ }^{*}, P<0.05, v s . \mathrm{H}_{2} \mathrm{O}_{2}, \mathrm{n}=8$. (C) Analysis of microRNA-126a-5p mimic or inhibitor effects on LDH release in $\mathrm{H}_{2} \mathrm{O}_{2}$-treated $\mathrm{H} 9 \mathrm{C} 2$ cardiomyocytes. *, $P<0.05$, vs. $\mathrm{H}_{2} \mathrm{O}_{2}, \mathrm{n}=8$. (D) Analysis of microRNA-126a-5p mimic or inhibitor effect on Caspase 3 activity in $\mathrm{H}_{2} \mathrm{O}_{2}$-treated $\mathrm{H} 9 \mathrm{C} 2$ cardiomyocytes. ", $P<0.05$, vs $\mathrm{H}_{2} \mathrm{O}_{2}, \mathrm{n}=8$. (E) After transfected with microRNA-126a-5p mimic or inhibitor, $\mathrm{H} 9 \mathrm{C} 2$ cells were exposed to $4 \mathrm{~h}$ of $\mathrm{Na}_{2} \mathrm{~S}_{2} \mathrm{O}_{4}$ and then to $12 \mathrm{~h}$ of reoxygenation, cell viability was analyzed by MTT. *, P $<0.05$, vs. Cont group; \#, $\mathrm{P}<0.05$, vs. H/R group, $\mathrm{n}=6$. M: microRNA126a-5p mimic; MN: microRNA126a-5p mimic negative; I: microRNA126a-5p inhibitor; IN: microRNA-126a-5p inhibitor negative. 
the mice among three groups. These results indicate that inhibition of cardiac microRNA-126a-5p could improve the ventricular contractility reflected by the increase in $+\mathrm{dp} /$ $\mathrm{dt}_{\max }$ and LVSP.

\section{Effect of microRNA-126a-5p ablation on cardiac function assessed by M-mode echocardiography}

Further, we tested the effect of microRNA-126a$5 \mathrm{p}$ ablation on the left ventricular cardiac function by echocardiography measurements. To verify this effect, transthoracic echocardiography and M-mode tracings were used to evaluate LVIDd, LVIDs, LVFS\% and LVEF\%. As expected, I/R injury significantly increased the LVIDd and LVIDs (Figure 6A and 6B), while reduced LVFS\% and $\mathrm{LVEF} \%$ (Figure 6C and 6D) relative to sham group. No significant difference was seen in the heart rate in any group (data not shown). Next, the mice pre-treated with miR-126a-5p inhibitor displayed significantly reduced LVIDd and LVIDs, relative to $\mathrm{I} / \mathrm{R}$-injured mice, as

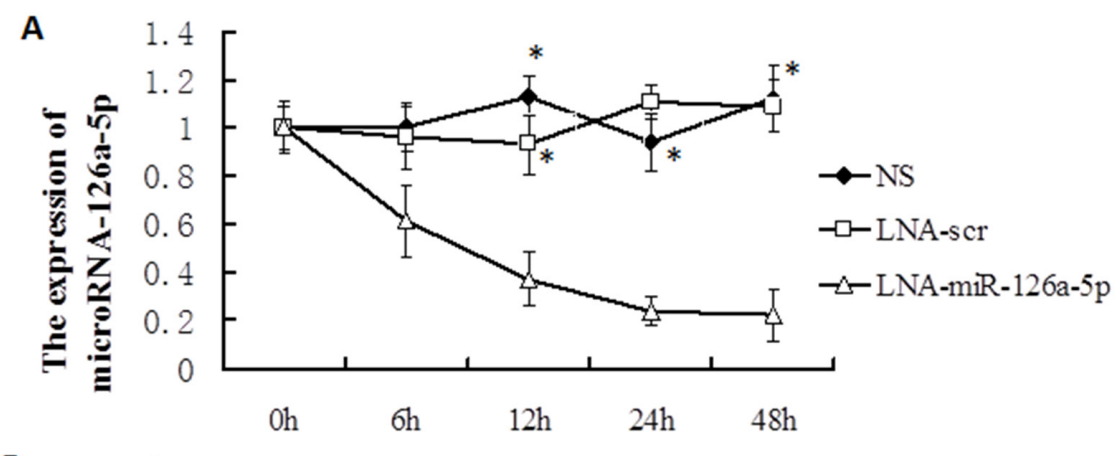

B
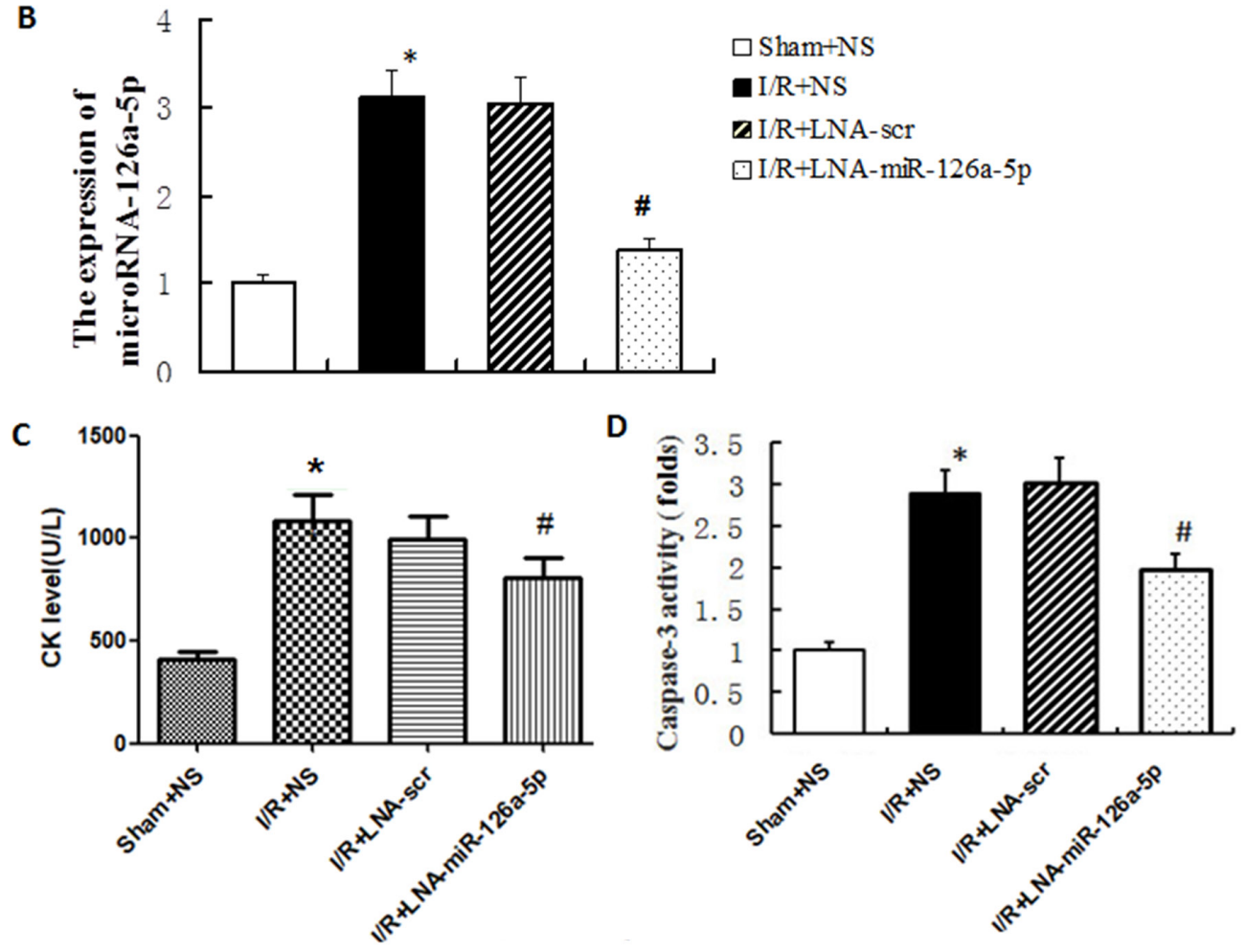

Figure 4: MicroRNA-126a-5p ablation alleviated the myocardial ischemia reperfusion injury in vivo. (A) The microRNA$126 \mathrm{a}-5 \mathrm{p}$ inhibitor effectively blocked microRNA-126a-5p expression in vivo. ${ }^{*}, P<0.01$, vs. $0 \mathrm{~h}, \mathrm{n}=5$. NS: normal saline group; LNAmicroRNA-126a-5p: microRNA-126a-5p inhibitor group; LNA-scr: microRNA-126a-5p inhibitor control group. (B) The microRNA126a-5p expression was inhibited by its inhibitor after $12 \mathrm{~h}$ of $\mathrm{I} / \mathrm{R}$ injury. ${ }^{*}, P<0.01$, $v s$. Sham $+\mathrm{NS}$ group, $\mathrm{n}=8$; $, P<0.01, v s$. I/R+LNA-scr group, $\mathrm{n}=8$. (C) Analysis of creatine kinase (CK) levels in mouse serum. ${ }^{*}, P<0.01$, vs. Sham $+\mathrm{NS}$ group, $\mathrm{n}=8$; $, P<0.01, v s$. I/R+LNAscr group, $\mathrm{n}=8$. (D) Analysis of myocardial caspase 3 activity. ",$P<0.01$, vs. Sham+NS group, $\mathrm{n}=8$; $, P<0.01, v s$. I/R+LNA-scr group, $\mathrm{n}=8$. Sham + NS: sham + saline injection group; $\mathrm{I} / \mathrm{R}+\mathrm{NS}$ : ischemia reperfusion injury + saline injection group; $\mathrm{I} / \mathrm{R}+\mathrm{LNA}-\mathrm{scr}$ : ischemia reperfusion injury + microRNA-126a-5p inhibitor control injection group; I/R+ LNA-microRNA-126a-5p: ischemia reperfusion injury + microRNA-126a-5p inhibitor injection group. 
shown in Figure 6A and 6B. Conversely, the LVFS\% and LVEF\% increased after treatment with microRNA-126a$5 \mathrm{p}$ inhibitor (Figure 6C and 6D). However, the scramble/ control inhibitor had no effect on I/R-induced cardiac injury.

\section{Hspb8 is a direct target gene of microRNA-126a- $5 p$}

It is well known that microRNAs exert their functions through suppressing target gene expression. Several bioinformatic websites, such as PicTar (http://pictar.mdcberlin.de/), TargetScan (http://www.targetscan.org/) and
miRBase (http://www.mirbase.org/) were used to predict the targets of microRNA-126a-5p. Among the candidates predicted by bioinformatics analysis, we found that $\mathrm{Hspb} 8$ is a potential target of microRNA-126a-5p because the seed sequences of microRNA-126a-5p align perfectly with the 3'-UTR of Hspb8 mRNA (Figure 7A). By transfecting H9C2 cells with miRNA mimics and inhibitors, we demonstrated microRNA-126a-5p mimic (M) significantly downregulated the mRNA and protein levels of Hspb8 and the expression of Hspb8 was significantly upregulated in microRNA-126a-5p inhibitor (I) group (Figure 7B and 7C).

Next, reporter constructs containing either wild-type (WT) Hspb8 3’-UTR or mutated Hspb8 3'-UTR (MT) at
A

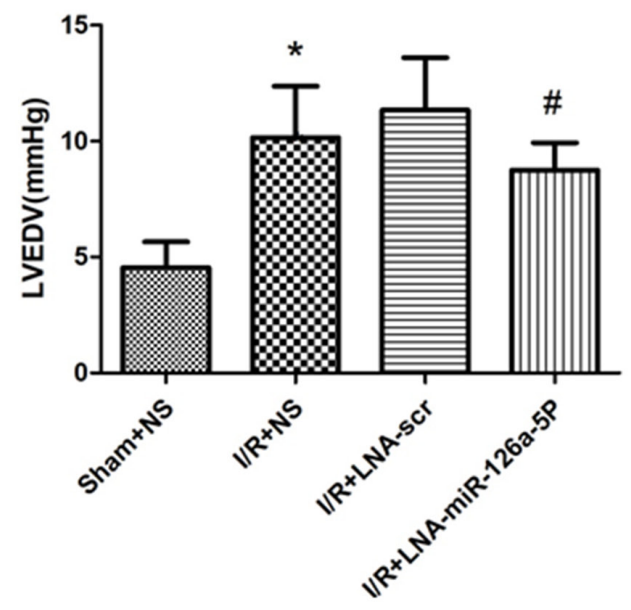

C

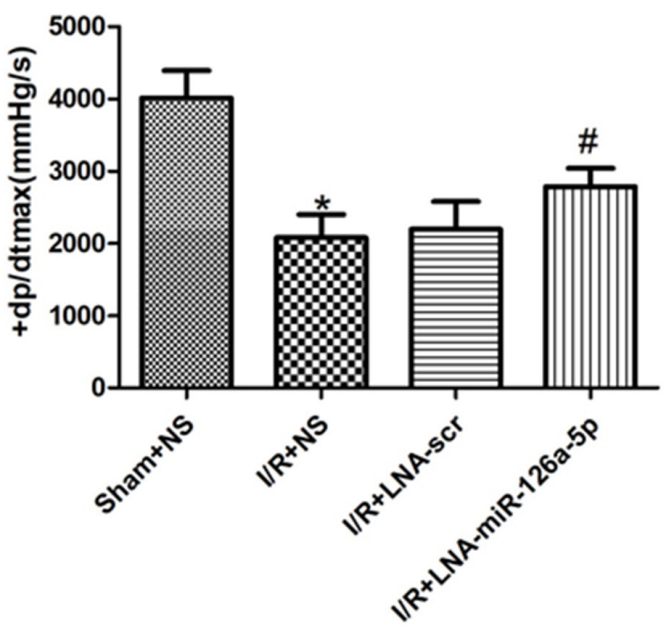

D
B

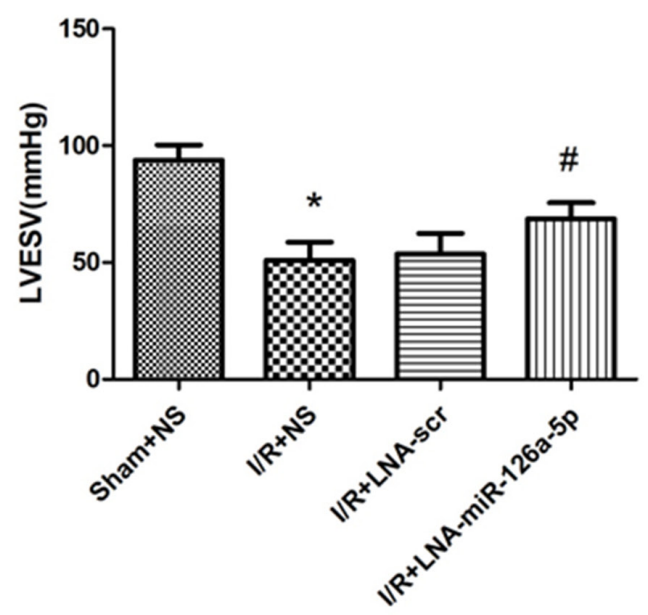

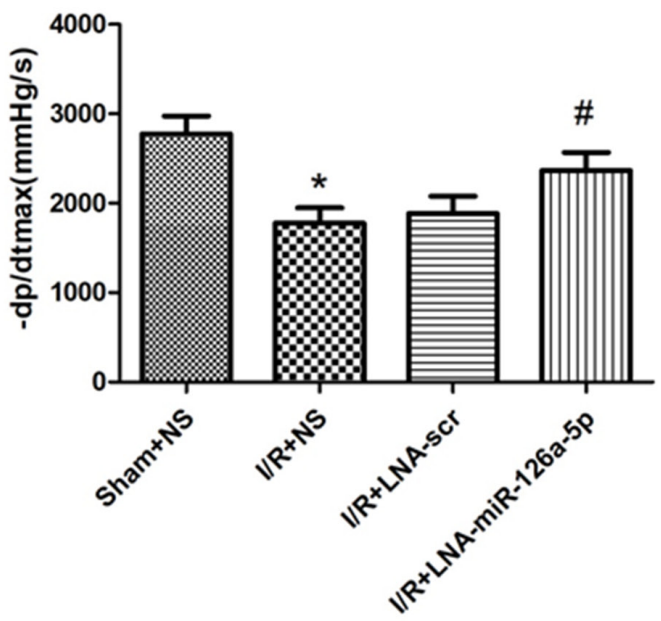

Figure 5: Effect of microRNA-126a-5p ablation on cardiac haemodynamic measurement. Powerlab was used to detect the effect of microRNA-126a-5p inhibitor on cardiac functions in mice. LVEDP: left ventricular end-diastolic pressure. LVSP: Left ventricular systolic pressure. $+\mathrm{dp} / \mathrm{dt}_{\max }$ : the maximum rate of left ventricular pressure rise; $-\mathrm{dp} / \mathrm{dt}_{\max }$, the maximum rate of left ventricle diastolic pressure change; ${ }^{\prime}, P<0.01$, vs. Sham $+\mathrm{NS}$ group, $\mathrm{n}=8 ;{ }^{\#}, P<0.01$, vs. I/R+LNA-scr group, $\mathrm{n}=8$. Sham+NS: sham + saline injection group; $\mathrm{I} / \mathrm{R}+\mathrm{NS}$ : ischemia reperfusion injury + saline injection group; $\mathrm{I} / \mathrm{R}+\mathrm{LNA}$-scr: ischemia reperfusion injury + microRNA-126a-5p inhibitor control injection group; I/R+ LNA-microRNA-126a-5p: ischemia reperfusion injury + microRNA-126a-5p inhibitor injection group. 
the predicted microRNA-126a-5p target sequences was transfected into $293 \mathrm{~T}$ cells and then co-transfected with mimic-NC, microRNA-126a-5p mimic, microRNA-126a$5 p$ inhibitor or inhibitor-NC. Luciferase reporter assays showed that microRNA-126a-5p mimic significantly decreased the luciferase activity of the WT Hspb8 3'UTR by approximately $37.3 \%$ in $293 \mathrm{~T}$ cells relative to the control ( $p<0.05$, Figure 7D), whereas microRNA-126a$5 \mathrm{p}$ inhibitor substantially increased luciferase activities of WT Hspb8 3'-UTR compared with inhibitor-NC $(\mathrm{p}<0.05$, Figure 7E). These results demonstrate that Hspb8 is the direct target of microRNA-126a-5p.

\section{Hspb8 siRNA inhibited the microRNA-126a-5p inhibitor-mediated protection against $\mathrm{H}_{2} \mathrm{O}_{2}^{-}$ induced injury}

Our finding that Hspb8 is a direct target gene of microRNA-126a-5p raised the possibility that $\mathrm{Hspb} 8$ levels may be the intermediate between microRNA- 126a-5p and M-I/R injury. To test this possibility, we investigated the effect of microRNA-126a-5p on Hspb8 expression in the animal and cell model of $\mathrm{I} / \mathrm{R}$ injury. Western blot analyses demonstrated that Hspb8 expression was down-regulated significantly after reperfusion $12 \mathrm{~h}$, and treatment with microRNA-126a-5p inhibitor (LNAmiR-126a-5p) inhibited the down-regulation of Hsbp8 in vivo (Figure 8A). Similarly, after exposure to $\mathrm{H}_{2} \mathrm{O}_{2}$ for 24h, Hspb8 expression was down-regulated significantly and further decreased in the cells transfected with microRNA-126a-5p mimic, but the change was reversed by microRNA-126a-5p inhibitor (Figure 8B).

To further confirm a role for Hspb8, Hspb8specific siRNAs were used to inhibit Hspb8 expression. Western blot analysis showed H9C2 cells transfected with Hspb8-specific siRNAs achieved $\sim 73 \%$ (\#1) and $\sim 67 \%$ (\#2) depletion of Hspb8, respectively (Figure 8C). Then the protection role of microRNA126a-5p inhibitor was observed after Hspb8 ablation. Consistent with the role as a target molecule of microRNA126a-5p, depletion of
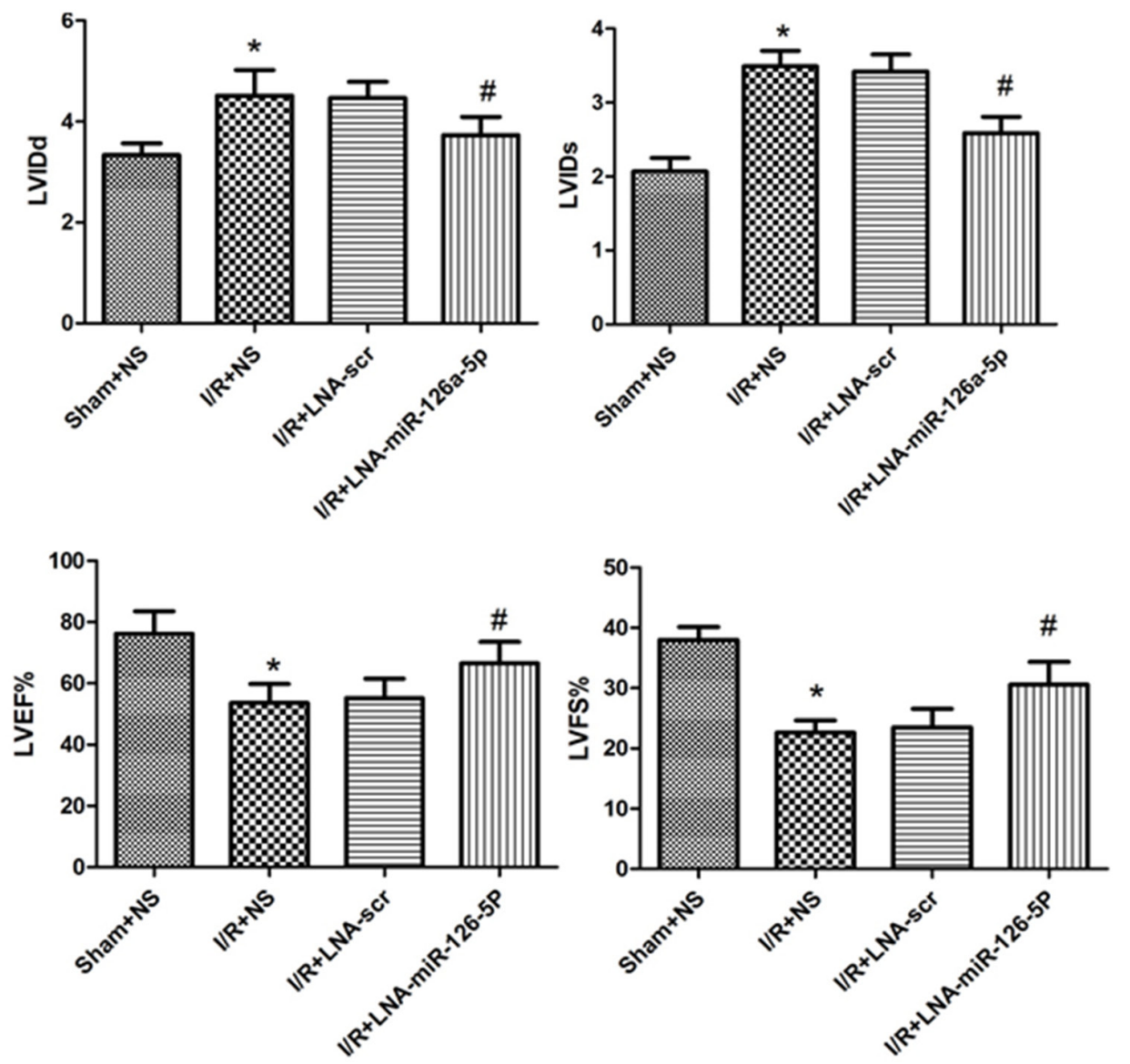

Figure 6: Effect of microRNA-126a-5p ablation on cardiac function by echocardiographic assessment. Echocardiography was performed as described in Methods section. LVIDd: left-ventricular internal diastolic diameter; LVIDs: left-ventricular internal systolic diameter; LVEF: left-ventricular ejection fraction; LVFS:left-ventricular percent fractional shortening. ${ }^{*}, P<0.01 v s$. Sham $+\mathrm{NS}$ group, $\mathrm{n}=8$; \#, $P<0.01$ vs. I/R+LNA-scr group, $\mathrm{n}=8$. Sham+NS: sham + saline injection group; I/R+NS: ischemia reperfusion injury + saline injection group; I/R+LNA-scr: ischemia reperfusion injury + microRNA-126a-5p inhibitor control injection group; I/R+ LNA-microRNA-126a-5p: ischemia reperfusion injury + microRNA-126a-5p inhibitor injection group. 
Hspb8 relieved the protective role of microRNA126a$5 \mathrm{p}$ inhibitor. Cell viability was robustly decreased after $\mathrm{H}_{2} \mathrm{O}_{2}$ treatment. Treatment with microRNA-126a-5p inhibitor significantly rescued $\mathrm{H}_{2} \mathrm{O}_{2}$-induced decrease in cell viability in $\mathrm{H} 9 \mathrm{C} 2$ cells $(p<0.05)$, however, treatment with Hspb8-specific siRNA (\#1) relieved the increase in cell viability mediated by microRNA-126a5 p inhibitor (Figure 8D). Moreover, caspase 3 activity
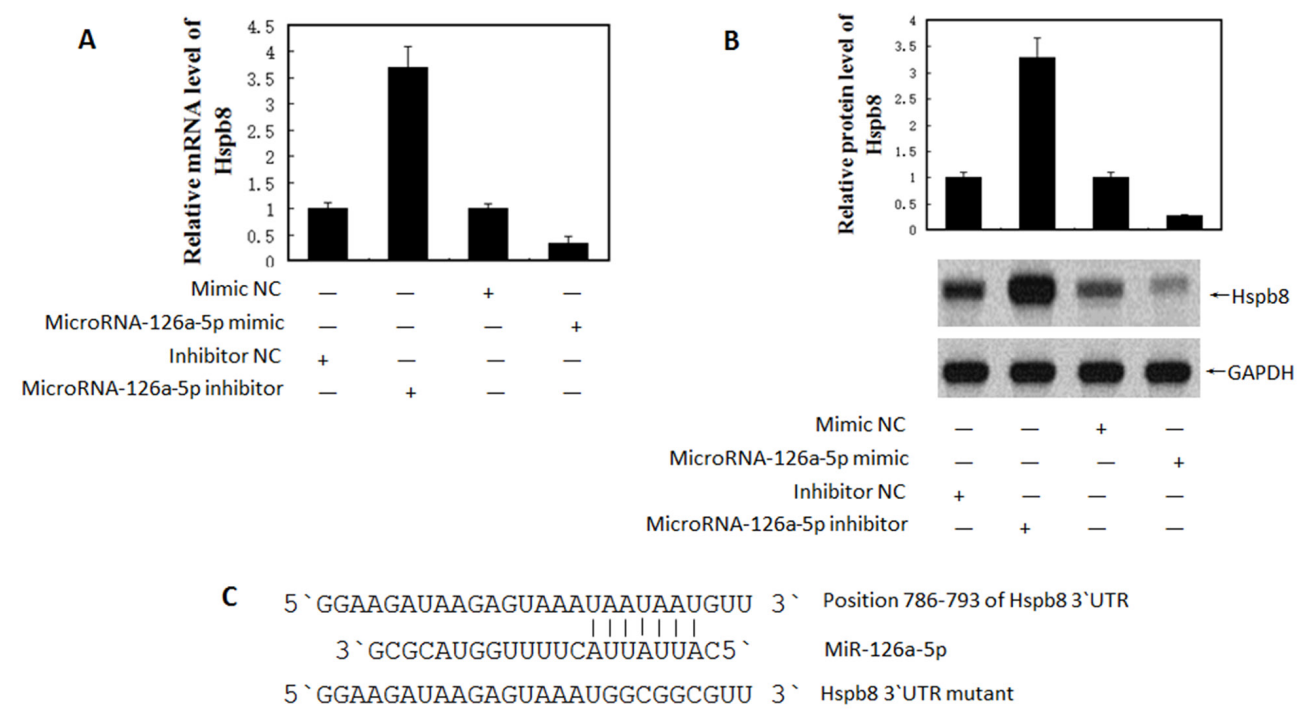

D
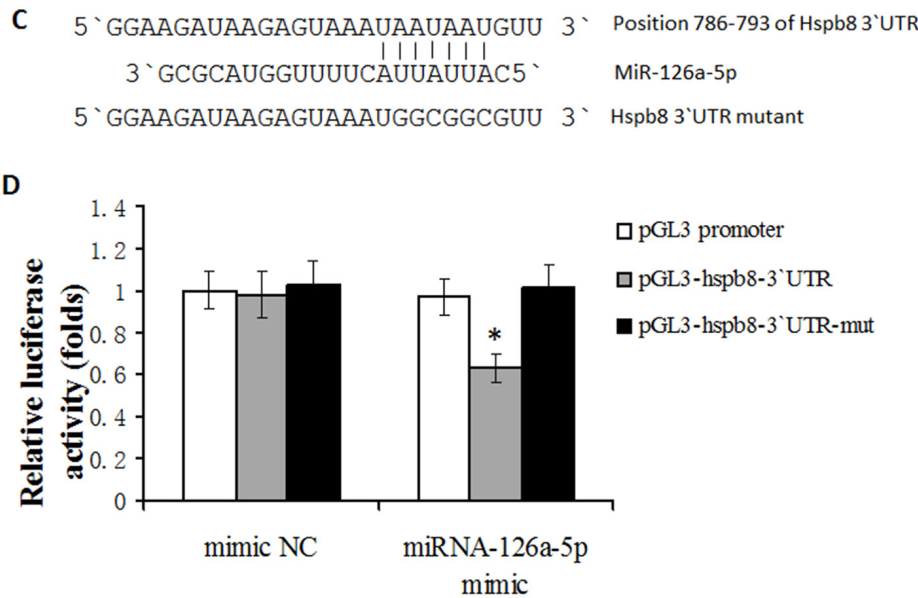

$\mathrm{E}$

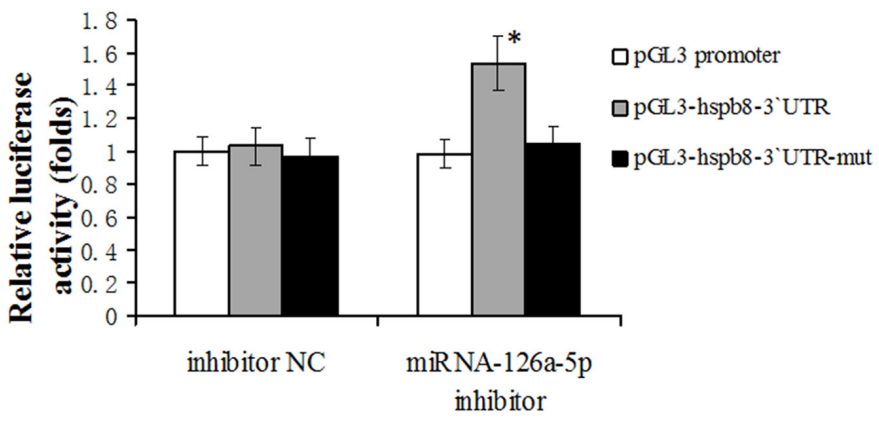

Figure 7: MicroRNA-126a-5p downregulated Hspb8 expression by binding to its 3'-untranslated region (3`UTR). (A) Hspb8 expression was significantly decreased by microRNA-126a-5p mimic while increased by microRNA-126a-5p inhibitor at mRNA level. $\left(\mathrm{n}=3,{ }^{*} \mathrm{P}<0.05\right)$. (B) Hspb8 protein expression was decreased by microRNA-126a-5p mimic while increased by microRNA-126a$5 \mathrm{p}$ inhibitor at protein level. (C) Schematic diagrams of the luciferase reporter construction. Wild type (pGL-hspb8-3'UTR) and mutant (pGL-hspb8-3 'UTR-mut) 3`UTR of Hspb8 containing the binding site with microRNA-126a-5p were inserted into pGL promoter vector. (D, E) HEK293 cells were transfected with microRNA-126a-5p mimic (D)/inhibitor(E) combined with luciferase reporter (Wt). The effect of microRNA-126a-5p on the luciferase activity was measured by luciferase reporter assays. MicroRNA-126a-5p could suppress while its inhibitor promoted the luciferase activity. On the other hand, the microRNA-126a-5p binding sites were mutated and the mutated luciferase reporters were co-transfected with microRNA-126a-5p mimic/inhibitor. The mutations on binding sites abolished the previously suppressive or promoted effects. ( $\mathrm{n}=3$ each group, $\left.{ }^{*} \mathrm{P}<0.05\right)$. 
was significantly increased following $\mathrm{H}_{2} \mathrm{O}_{2}$ exposure, and microRNA-126a-5p inhibitor reversed the increase of caspase 3 activity. However, Hspb8-specific siRNA (\#1) inhibited the changes of caspase 3 activity mediated by microRNA-126a-5p inhibitor (Figure 8E).

\section{DISCUSSION}

Myocardial ischemia and reperfusion (I/R) injury is a phenomenon where blood supply to the heart is restricted momentarily and then restored back, but the damages to the tissues and organs may not recover completely. This is a complex pathophysiological event involving various mechanisms. The myocardial $\mathrm{I} / \mathrm{R}$ injury induces the myocardial damage including cell death, cardiomyocyte hypertrophy and angiogenesis. There are many factors that can lead to cell death, such as $\mathrm{pH}$ abnormality [16], cellular calcium overload [17], oxidative stress [18], and release of inflammatory mediators [19]. The death of cardiomyocytes causes heart dysfunction and may eventually lead to heart failure. Thus, it is important to find some effective ways to prevent cell death from M-I/R injury. In our study, we observed that $\mathrm{M}-\mathrm{I} / \mathrm{R}$-mediated injury to heart is mainly reflected in disorderly arrangement and dissolvement of myocardial fibers, infiltration by inflammatory cells and the increase in serum LDH, CK-MB levels.

MicroRNAs function as gene silencers and are emerging as important regulators for gene expression and biological processes. Recently, several studies have suggested that miRNAs are involved in cardiac events such as muscle contraction, heart growth and conductance of electric signal [20]. They play an important role in myocardial remodeling [21], arrhythmia [1], atherosclerosis [22] and myocardial regeneration [23]. It has been demonstrated that upregulation of miR22 contributes to $\mathrm{M}-\mathrm{I} / \mathrm{R}$ injury by interfering with the mitochondrial function [24]. MicroRNA-128 inhibitor attenuates the apoptosis of cardiomyocytes during M-I/R injury through the activation of peroxisome proliferatoractivated receptor gamma [25]. Moreover, miR-93 inhibits ischemia reperfusion-induced cardiomyocyte apoptosis by targeting PTEN [26]. MiR-195 may promote cardiomyocyte apoptosis by targeting Bcl-2 and inducing mitochondrial apoptotic pathway during ischemia reperfusion-induced myocardial injury [27]. Considering that multiple miRNAs play important roles in $\mathrm{M}-\mathrm{I} / \mathrm{R}$ injury, it is necessary to identify the differentially expressed microRNAs during myocardial I/R injury. In this study, a comparative miRNA profiling was performed in myocardium between sham group and I/R group. In response to $\mathrm{I} / \mathrm{R}$ injury, remarkable change of miRNAs in myocardium was observed. MicroRNA-126a-5p was identified as one of the differentially expressed miRNAs compared to its expression in normal heart tissue.

MicroRNA-126a-5p is one of the miRNAs located on the intron of epidermal growth factor like domain 7 gene [13]. The in vivo and in vitro studies have indicated that microRNA-126a-5p plays crucial roles in maintaining the integrity of blood vessels, the formation of new blood vessels and repairing of the damages [28-34]. Recently, Tang et al. found down-regulation of microRNA-126a-5p leads to overexpression of VEGFA in lipopolysaccharide-induced acute lung injury [35]. But the function of microRNA-126a$5 \mathrm{p}$ in myocardial I/R injury is still unknown.

In this study, we observed the expression of microRNA-126a-5p in M-I/R injury mouse model and RT-QPCR results revealed that $\mathrm{I} / \mathrm{R}$ injury increased the expression of microRNA-126a-5p. In parallel, we observed that $\mathrm{H}_{2} \mathrm{O}_{2}$ or $\mathrm{H} / \mathrm{R}$-induced injury in $\mathrm{H} 9 \mathrm{C} 2$ cardiomyocytes also increased microRNA-126a-5p expression. To further study whether microRNA-126a$5 \mathrm{p}$ is involved in mediating $\mathrm{H}_{2} \mathrm{O}_{2}$-induced cardiac muscle cell injury or not, we modulated microRNA-126a-5p expression by using its mimic and inhibitor. Upregulation of microRNA-126a-5p expression via its mimic promoted the $\mathrm{H}_{2} \mathrm{O}_{2}$-induced apoptosis and the release of $\mathrm{LDH}$. Conversely, $\mathrm{H}_{2} \mathrm{O}_{2}$-induced apoptosis and $\mathrm{LDH}$ release were inhibited by down-regulation of microRNA-126a-5p expression by microRNA-126a-5p inhibitor. These results clearly suggest that microRNA-126a-5p can inhibit cell activity and promote cell apoptosis.

To further validate the observation, we investigated the role of microRNA-126a-5p during M-I/R injury in vivo. Injection of microRNA-126a-5p inhibitor to mice through tail vein led to the reduction of its endogenous expression. This allowed us to study the role of microRNA-126a-5p during M-I/R injury. Down-regulation of microRNA-126a-5p expression by its inhibitor in mice with $\mathrm{I} / \mathrm{R}$ injury could reduce $\mathrm{I} / \mathrm{R}$ injury-mediated $\mathrm{CK}-\mathrm{MB}$ expression and myocardial caspase- 3 activity. Similarly, it also resulted in the improvement of hemodynamic indexes and cardiac function. Thus, lower expression of microRNA-126a-5p can attenuate the effects triggered by $\mathrm{M}-\mathrm{I} / \mathrm{R}$ injury.

MicroRNAs play a critical role in various biological activities through post-transcriptional suppression. By using online bioinformatics tools, Hspb8 was predicted to be a target gene of microRNA-126a-5p and we further confirmed this prediction by using biological assays. Hspb8, also named heat shock protein 22/H11 Kinase (Hsp22), is the stress-inducible small heat shock protein responsive to various conditions of myocardial stress, including ischemia [36]. Hspb8 is highly expressed in cardiac tissue [37]. Cardiac-specific overexpression of Hspb8 in a transgenic mouse provides protection against myocardial ischemia that is equally powerful to ischemic preconditioning through the induction of the inducible isoform of nitric oxide synthase (iNOS) [38].

In summary, our results demonstrated that microRNA-126a-5p expression was up-regulated during $\mathrm{M}-\mathrm{I} / \mathrm{R}$ injury. Over-expression of microRNA-126a$5 \mathrm{p}$ inhibited cell viability and promoted cell apoptosis, 

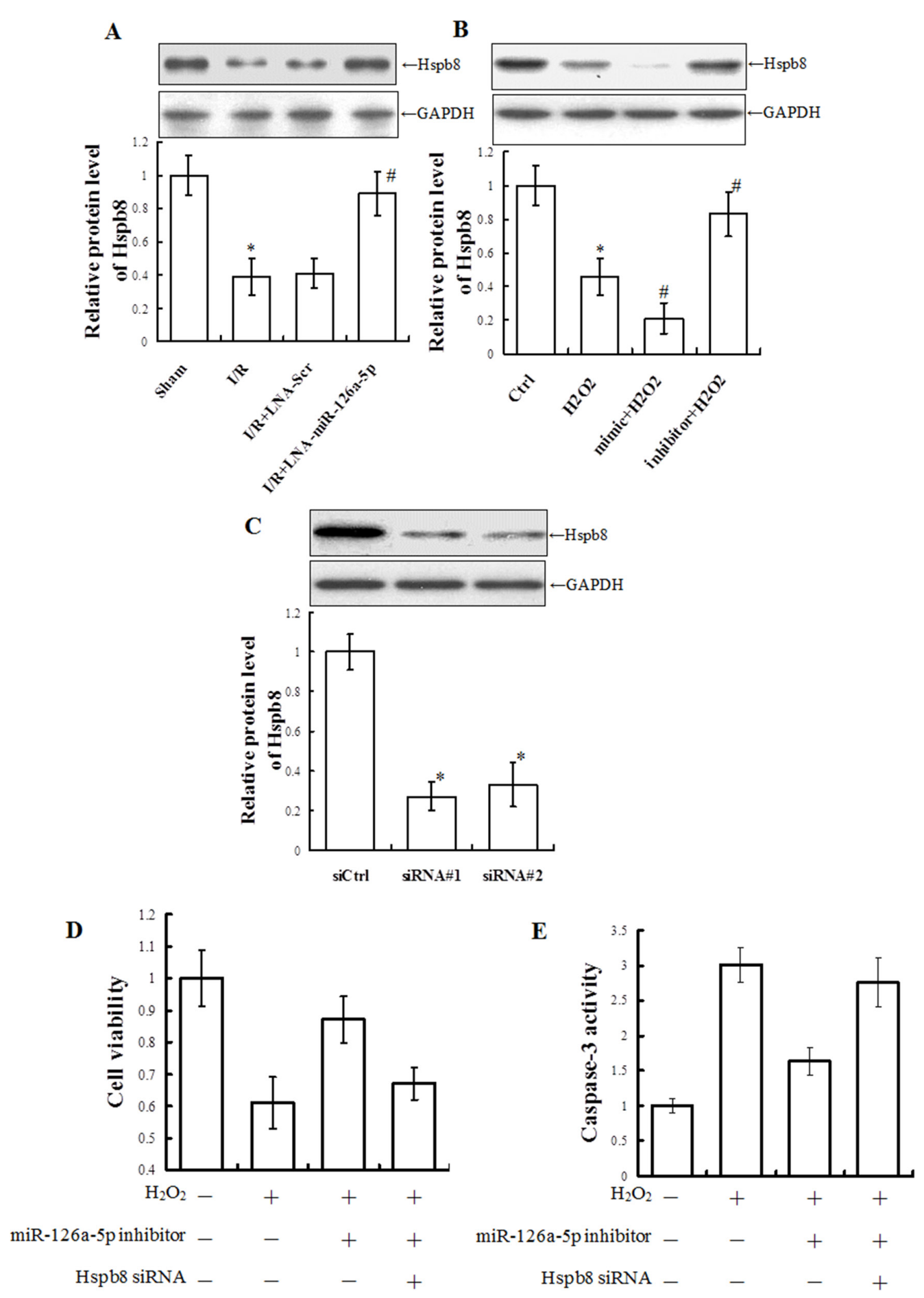

Figure 8: Hspb8 siRNA inhibited microRNA-126a-5p inhibitor-mediated protection against $\mathrm{H}_{2} \mathrm{O}_{2}$-induced injury in H9C2 cells. (A) Western blot analysis of Hspb8 levels in total tissue extracts from infarct zone tissue treated with microRNA-126a-5p inhibitor (LNA-miR-126a-5p) or control inhibitor (LNA-Scr). ${ }^{*}, P<0.05$, vs. Sham group, $\mathrm{n}=6$; ${ }^{*}, P<0.05, v s$. I/R+LNA-scr group, $\mathrm{n}=6$. (B) Western blot analysis of Hspb8 levels in total cell extracts prepared from $\mathrm{H} 9 \mathrm{C} 2$ cells treated with microRNA-126a-5p mimic or inhibitor. ",$P<0.05$, vs. Ctrl group, $\mathrm{n}=8$; ${ }^{*}, P<0.05, v s . \mathrm{H}_{2} \mathrm{O}_{2}$ group, $\mathrm{n}=8$. (C) Analysis of Hspb8 levels total cell extracts prepared from H9C2 cells transfected with control siRNA (siCtrl) or HSPB8-specific siRNAs. siRNA \#1: \#195633; siRNA \#2: \#195635. ", $P<0.05$, vs. siCtrl group, $\mathrm{n}=4$. (D, E) Analysis ofcell viability (D) and caspase 3 activity (E) in $\mathrm{H} 9 \mathrm{C} 2$ cells exposed to $\mathrm{H}_{2} \mathrm{O}_{2}$ for $24 \mathrm{~h}$ after co-transfection with microRNA-126a-5p inhibitor and Hspb8 siRNA \#1 for 24h. ${ }^{*}, P<0.05, v s . \mathrm{H}_{2} \mathrm{O}_{2}$ group, $\mathrm{n}=6$; ${ }^{*}, P<0.05, v s$. inhibitor $+\mathrm{H}_{2} \mathrm{O}_{2}$ group, $\mathrm{n}=6$. 
while the inhibition of microRNA-126a-5p protected the myocardium from the damages during M- I/R injury in vitro and in vivo through targeting Hspb8. These findings not only provide solid evidence for the mechanisms of myocardial $\mathrm{I} / \mathrm{R}$ injury but also provide preclinical evidence that microRNA-126a-5p may be considered as a new therapeutic target to intervene the myocardial I/R injury.

\section{MATERIALS AND METHODS}

\section{Materials}

Adult male wild-type C57BL/6 mice weighing about 18-22 g were purchased from the Animal Center, Central South University (Changsha, China). The mice were housed in a temperature- and humidity-controlled animal room at $25^{\circ} \mathrm{C}$ with a $12: 12 \mathrm{~h}$ day/night cycle. H9C2 cardiomyocyte cell line was purchased from American type culture collection (ATCC) and grown in Dulbecco's Modified Eagle (DMEM) medium supplemented with $10 \%$ fetal bovine serum at $37^{\circ} \mathrm{C}$ with $5 \% \mathrm{CO}_{2}$. Syn-mmumicroRNA-126a-5p miScript miRNA Mimic (Code: MSY00013), anti-mmu-126-5p miScript miRNA inhibitor (CodeMIN000137), AllStar negative control siRNA (Code: 1027280), miScript inhibitor negative control (Code: 1027271) and Hiperfect transfection reagent were purchased from Qiagen Corporation. MiRCURY LNA (Locked Nucleic Acid) microRNA-126a-5p mouse inhibitor was procured from Exiqon (Vedbaek, Denmark). The sequences of miRCURY LNA microRNA-126a-5p inhibitor are 5'-CGCGTACCAAAAGTAATAATG-3`and the sequences of miRCURY LNA control microRNA inhibitor are 5'-GTGTAACACGTCTATACGCCCA-3`. DEPC, $\mathrm{H}_{2} \mathrm{O}_{2}$ and sodium dithionite $\left(\mathrm{Na}_{2} \mathrm{~S}_{2} \mathrm{O}_{4}\right)$ were purchased from Sigma Corporation (St. Louis, MO). Caspase-3 and LDH kits were purchased from Beyotime Corporation (Shanghai, China). Negative control-siRNA (Silencer ${ }^{\circledR}$ Negative Control \#1 siRNA), Hspb8-siRNAs (Silencer® siRNA, \#195633 and \#195635) were obtained from Thermo Fisher Scientific, Corp. (Frederick, MD, USA).

\section{Methods}

\section{Development of in vivo mouse model for M-I/R injury}

All adult male C57BL/6 mice with similar body weight were anesthetized by intraperitoneal (i.p.) injection of ketamine $(100 \mathrm{mg} / \mathrm{kg}$ ) and xylazin (Rompun $10 \mathrm{mg} /$ $\mathrm{kg}$ ) before endotracheal intubation. Then mouse's thoracic cavity was opened by left thoracotomy, and 8-0 prolene suture was passed under the left anterior descending (LAD) coronary artery located at the inferior edge of the left atrium and tied to produce an occlusion. After LAD coronary artery ligation, the persistent elevation of the ST segment was located. This led to the successful confirmation of the ischemia model. Post 30 mins of ischemia induction, the ligature was released and mice were reperfused for different time points. At last, the chest of mouse was closed with 6-0 prolene sutures and endotracheal tube was removed to resume spontaneous respiration. In addition, the sham group mice were operated similarly, except the ligation of the left anterior descending coronary artery. At the time of sacrifice, anesthesia was induced by isoflurane (3\% induction, $1.5 \%$ maintenance). The myocardial tissues from the infarct zone and blood were harvested for morphology, quantitative and qualitative analysis.

\section{Hematoxylin-eosin staining}

The myocardial tissues from the infarct zone were quickly collected and fixed with 4\% neutral-buffered paraformaldehyde for $24 \mathrm{hrs}$, according to the standard procedure. The $5 \mathrm{~mm}$ thick sections were embedded in paraffin. Next, H\&E staining was used to examine the change in myocardial tissue morphology. These stained sections were examined under optical microscope to assess the degree of heart damage and subsequently photographed.

\section{Assessment of creatine kinase and LDH in the serum}

The assessment of creatine kinase and LDH serum levels was performed as described previously [40, 41].

\section{Sample collection and total RNA extraction}

The myocardial tissues from the infarct zone were immediately frozen in the liquid nitrogen. Then the samples were homogenized in RNase-free mortars with liquid nitrogen and TRIzol reagent (Invitrogen, USA), and total RNA was extracted.

\section{MicroRNA microarray}

Sample labeling, microarray hybridization, and wash were performed based on the manufacturer's standard protocols (Agilent Technologies Inc., Santa Clara, California, USA). After dephosphorylation and denaturation, total RNA was labeled with cyanine 3-pCp and then hybridized to Agilent miRNA Microarray V2.0. Following hybridization for $20 \mathrm{hrs}$, the slides were washed using the Gene Expression Wash Buffer Kit (Agilent) and scanned using an Agilent Scanner. The images were processed and analyzed with Agilent Feature Extraction Software. The raw data were normalized using quantile normalization and then analyzed by GeneSpring GX software (zcomSilicon Genetics, Redwood City, CA, USA). Statistical analysis was conducted by using ANOVA to compare the differentially expressed miRNAs. The threshold set for significantly up- and down-regulated genes was fold change $>2.0$ and $\mathrm{P}$ value $<0.05$. 


\section{Quantitative real-time PCR for microRNA-126a- 5p expression}

Total RNA was isolated from the heart tissues and H9C2 cells using the miRNeasy mini kit (Qiagen). The miScript reverse transcription kit (Qiagen) and miScript SYBR Green PCR kit (Qiagen) were used to measure the expression levels of microRNA-126a-5p with its specific primers and the miScript Universal Primer (Qiagen), using a Fast Real-Time PCR system, model 7500 (Applied Biosystems, Foster City, CA, USA). All reactions were incubated at $95^{\circ} \mathrm{C}$ for $30 \mathrm{~s}$, followed by 40 cycles of $95^{\circ} \mathrm{C}$ for $5 \mathrm{~s}$ and $60^{\circ} \mathrm{C}$ for $34 \mathrm{~s}$ Expression level of the U6B small nuclear RNA (RNU6B) was used as an endogenous control to normalize the sample data. Relative expression levels were calculated with the $2^{-\Delta \Delta \mathrm{Ct}}$ method. Every experiment was repeated at least three times.

\section{Treatment of $\mathrm{H} 9 \mathrm{C} 2$ cells with $\mathrm{H}_{2} \mathrm{O}_{2}$}

H9C2 cells $\left(1 \times 10^{4}-1 \times 10^{5}\right)$ were seeded into each well of 96-well plates. They were treated with various concentrations $(0 \mathrm{mg} / \mathrm{L}, 0.25 \mathrm{mg} / \mathrm{L}, 0.5 \mathrm{mg} / \mathrm{L}, 0.75 \mathrm{mg} / \mathrm{L}$, $1 \mathrm{mg} / \mathrm{L}$ ) of $\mathrm{H}_{2} \mathrm{O}_{2}$ for $24 \mathrm{hrs}$ or treated with $0.5 \mathrm{mg} / \mathrm{L}$ of $\mathrm{H}_{2} \mathrm{O}_{2}$ for different time points $(0 \mathrm{hr}, 6 \mathrm{hrs}, 12 \mathrm{hrs}$ and 24 hrs).

\section{Preparation of cardiomyocyte hypoxia/ reoxygenation model}

Cardiomyocytes hypoxia/reoxygenation model was prepared by $\mathrm{Na}_{2} \mathrm{~S}_{2} \mathrm{O}_{4}$ as described previously [39] with some modifications. The H9c2 cells were exposed to $\mathrm{Na}_{2} \mathrm{~S}_{2} \mathrm{O}_{4}$ at a concentration of $4 \mathrm{mM}$ in the low glucose DMEM medium for $4 \mathrm{~h}$ at $37^{\circ} \mathrm{C}$ and $5 \% \mathrm{CO}_{2}$, causing hypoxia-induced damage. Then, the medium was replaced with normal medium (high glucose) for $12 \mathrm{~h}$ at $37^{\circ} \mathrm{C}$ and $5 \% \mathrm{CO}_{2}$. The viability of $\mathrm{H} 9 \mathrm{C} 2$ cells treated with $\mathrm{Na}_{2} \mathrm{~S}_{2} \mathrm{O}_{4}$ was assessed by MTT assay.

\section{Cell transfection}

H9C2 cells were transfected with microRNA-126a$5 \mathrm{p}$ mimic or inhibitor according to the manufacturer's protocols. Firstly, $1.0 \times 10^{5}$ cells were seeded in each well of 24-well plate and cultured under normal growth conditions (typically $37^{\circ} \mathrm{C}$ and $5 \% \mathrm{CO}_{2}$ ). Next, $0.15 \mu$ of miRNA mimic or $1.5 \mu \mathrm{l}$ of miRNA inhibitor was diluted in $100 \mu \mathrm{l}$ culture medium without serum, followed by the addition of $3 \mu \mathrm{l}$ of HiPerFect transfection reagent to the diluted miRNA mimic/ inhibitor mixture by vortexing. The mixture was incubated for 5-10 mins at room temperature and added drop-wise onto the culture medium. Finally, cells were incubated with this transfection mixture under normal growth conditions for 24 hrs and microRNA-126a-5p expression was detected by RTQPCR. To knockdown Hspb8 in H9C2 cells, the cells were transfected with Hspb8 siRNAs (\#195633 and \#195635) or the negative control siRNA using HiPerFect transfection reagent in accordance with the manufacturer's instructions. After transfection for $48 \mathrm{~h}, \mathrm{Hspb} 8$ protein expression was analyzed by Western blot.

\section{Cell viability, caspase 3 activity assay and western blot}

The caspase activity assay, cell viability assay, and western blot were performed as described previously [40, 41]. Rabbit monoclonal anti-hspb8 antibody (ab151552, Abcam) and Rabbit monoclonal anti-GAPDH antibody (2118L, cell signaling) were used.

\section{Knockdown of microRNA-126a-5p in mice}

Healthy male C57BL/6 mice weighing 18-22 $\mathrm{g}$ were randomly divided into four groups: (1) the sham+NS group $(n=8)$ : these mice underwent sham operation without coronary artery ligation and received normal saline injection via tail vein; (2) the $\mathrm{I} / \mathrm{R}+\mathrm{NS}$ group $(n=8)$ : the mice received ischemia induction for $30 \mathrm{~min}$ followed by $12 \mathrm{hrs}$ reperfusion, and were then injected with normal saline via tail vein; (3) the $I / R$ + microRNA-126a-5p inhibitor control group $(n=8)$ : these mice underwent ischemia induction for $30 \mathrm{~min}$ followed by $12 \mathrm{hrs}$ reperfusion, and were injected with microRNA-126a-5p control inhibitor via tail vein; (4) the $\mathrm{I} / \mathrm{R}+$ microRNA-126a-5p inhibitor group $(\mathrm{n}=8)$ : the mice underwent ischemia induction for $30 \mathrm{~min}$ followed by 12 hrs reperfusion, and were then injected with microRNA126a-5p inhibitor via tail vein. After $12 \mathrm{hrs}$ of these control or inhibitor injection, we performed the echocardiography and cardiac haemodynamic measurements to assess the heart function. After measurements, the mice were sacrificed to collect the heart tissues and serum.

\section{Echocardiography analysis}

Mice were kept on a heating pad in a left lateral decubitus or supine position under isoflurane (2\%) anesthesia and two-dimensional images were recorded. LV parameters including interventricular septum thickness, LV posterior wall thickness, LV internal diastolic diameter (LVIDd) and LV internal systolic diameter (LVIDs) were obtained from M-mode interrogation in a long-axis view. The LV percentage fractional shortening (LV\%FS) and $\mathrm{LV}$ ejection fraction (LVEF) were calculated as follows: $\mathrm{LV} \% \mathrm{FS}=(\mathrm{LVIDd}-$ LVIDs)/LVIDd $\times 100$; and LVEF $=[($ LVIDd $) 3-($ LVIDs $) 3] /$ $($ LVIDd) $3 \times 100$. All echocardio-graphic measurements were averaged from at least three separate cardiac cycles.

\section{Hemodynamic measurements}

Hemodynamic measurements were performed in mice after $\mathrm{I} / \mathrm{R}$. Mice were kept under isoflurane (2\%) anesthesia. A Millar catheter (SPR-1000) was inserted 
through the right carotid artery into the LV. The LV systolic pressure (LVSP), LV end-diastolic pressure (LVEDP), maximum rate of LVSP increase $(+\mathrm{dp} / \mathrm{dt}$ max) and decrease $(-\mathrm{dp} / \mathrm{dt} \max )$ were recorded and analyzed using a PowerLab data acquisition system (model ML866; ADInstruments, Colorado Springs, CO).

\section{MicroRNA target prediction}

To predict the target genes of miR-126a-5p, bioinformatics algorithms TargetScan (http://www. targetscan.org) miRBase (http://www.mirbase.org/) and TargetScan (http://www.Targetscan.org/) were used.

\section{Hspb8 3'-UTR cloning and luciferase assay}

Luciferase reporter assay was performed as described previously [40]. A fragment of the Hspb8 3'UTR containing the predicted binding site or their mutant fragment sequence on each side with suitable enzyme cleavage sites were synthesized and cloned into the downstream of luciferase reporter gene (Hspb8 Wt-Luc or Hspb8 Mu-Luc). Each vector, along with Relina vector and microRNA-126a-5p mimics or negative control or microRNA-126a-5p inhibitor, anti-miR-126a-5p or Anti$\mathrm{NC}$, were transfected into $293 \mathrm{~T}$ cells using Lipofectamine 2000 reagent (Invitrogen, USA) following the instructions. Cells were harvested $48 \mathrm{~h}$ after transfection and luciferase activity was detected using the Dual-Luciferase Reporter Assay System (Promega, USA).

\section{Statistical analysis}

The data were represented as mean \pm SEM and all statistical analyses were performed using with GraphPad Prism 5 (GraphPad Software, Inc., San Diego, CA, USA). The differences between two groups were analyzed using unpaired Student's t-test, while the differences among three or more groups were analyzed using one-way ANOVA (analysis of variance) followed by StudentNewman-Keuls.

\section{Author contributions}

BJ and YL designed the study and drafted the manuscript. PL and YL carried out the animal follow-up study. YL and QL carried out the molecular mechanism studies, ZT and ML participated in the design of the study and performed the statistical analysis. ZL and XX designed the study and helped to draft the manuscript. All authors read and approved the final manuscript.

\section{CONFLICTS OF INTEREST}

The authors declare that they have no conflicts of interest.

\section{FUNDING}

This work was supported by the National Natural Science Foundation of China (Grant No. 81770306; 81170113; 81471868; 81370252).

\section{REFERENCES}

1. Li J, Donath S, Li Y, Qin D, Prabhakar BS, Li P. miR-30 regulates mitochondrial fission through targeting p53 and the dynamin-related protein-1 pathway. PLoS Genet. 2010; 6: e1000795.

2. Ambros V. The functions of animal microRNAs. Nature. 2004; 431: 350-355.

3. Friedman RC, Farh KK, Burge CB, Bartel DP. Most mammalian mRNAs are conserved targets of microRNAs. Genome Res. 2009; 19: 92-105.

4. Callis TE, Wang DZ. Taking microRNAs to heart. Trends Mol Med. 2008; 14: 254-260.

5. Garzon R, Pichiorri F, Palumbo T, Iuliano R, Cimmino A, Aqeilan R. MicroRNA fingerprints during human megakaryocytoposis. Pro Natl Acad Sci U S A. 2006; 103: 5078-5083.

6. Tavazoie SF, Alarcón C, Oskarsson T, Padua D, Wang Q, Bos PD, Gerald WL, Massague J. Endogenous human microRNAs that suppress breast cancer metastasis. Nature. 2008; 451: 147-152.

7. Almeida MI, Reis RM, Calin GA. MicroRNA history: discovery, recent applications, and next frontiers. Mutat Res. 2011; 717: 1-8.

8. Song CL, Liu B, Diao HY, Shi YF, Li YX, Zhang JC, Lu Y, Wang G, Liu J, Yu YP, Guo ZY, Wang JP, Zhao Z, et al. The protective effect of microRNA-320 on left ventricular remodeling after myocardial ischemia-reperfusion injury in the rat model. Int J Mol Sci. 2014; 15: 17442-17456.

9. Wang JX, Zhang XJ, Li Q, Wang K, Wang Y, Jiao JQ, Feng C, Teng S, Zhou LY, Gong Y, Zhou ZX, Liu J, Wang JL, Li PF. microrna-103/107 regulate programmed necrosis and myocardial ischemia/reperfusion injury through targeting FADD. Circ Res. 2015; 117: 352-363.

10. Liu RR, Li J, Gong JY, Kuang F, Liu JY, Zhang YS, Ma QL, Song CJ, Truax AD, Gao F, Yang K, Jin BQ, Chen LH. MicroRNA-141 regulates the expression level of ICAM-1 on endothelium to decrease myocardial ischemiareperfusion injury. Am J Physiol Heart Circ Physiol. 2015; 309: H1303-313.

11. Han Q, Zhang HY, Zhong BL, Zhang B, Chen H. Antiapoptotic effect of recombinant HMGB1 A-box Protein via regulation of microRNA-21 in myocardial ischemiareperfusion injury model in rats. DNA Cell Biol. 2016; 35 : 192-202.

12. Makhdoumi P, Roohbakhsh A, Karimi G. MicroRNAs regulate mitochondrial apoptotic pathway in myocardial 
ischemia-reperfusion-injury. Biomed Pharmacother. 2016; 84: 1635-1644.

13. Liu B, Peng XC, Zheng XL, Wang J, Qin YW. microRNA126a-5p restoration down-regulate VEGF and inhibit the growth of lung cancer cell lines in vitro and in vivo. Lung Cancer. 2009; 66: 169-175.

14. Qiang L, Hong L, Ningfu W, Huaihong C, Jing W. Expression of microRNA-126a-5p and miR-508-5p in endothelial progenitor cells is associated with the prognosis of chronicheart failure patients. Int J Cardiol. 2013; 168: 2082-2088.

15. Tang ST, Wang F, Shao $M$, Wang $Y$, Zhu HQ. MicroRNA-126 suppresses inflammation in endothelial cells under hyperglycemic condition by targeting HMGB1. Vascul Pharmacol. 2016; 88: 48-55.

16. Yellon DM, Hausenloy DJ. Myocardial reperfusion injury. N Engl J Med. 2007; 357: 1121-1135.

17. Lemasters JJ, Bond JM, Chacon E, Harper IS, Kaplan SH, Ohata H, Trollinger DR, Herman B, Cascio WE. The $\mathrm{pH}$ paradox in ischemia-reperfusion injury to cardiac myocytes. In myocardial ischemia: mechanisms, reperfusion, protection. Springer. 1996; 76: 99-114.

18. Piper H, Garcna-Dorado D, Ovize M. A fresh look at reperfusion injury. Cardiovasc Res. 1998; 38: 291-300.

19. Zweier J. Measurement of superoxide-derived free radicals in the reprfused heart. Eviddence for a free radical mechanism of reperfusion injury. J Biol Chem. 1998; 263: 1353-1357.

20. Zhao Y, Ransom JF, Li A, Vedantham V, von Drehle M, Muth AN, Tsuchihashi T, McManus MT, Schwartz RJ, Srivastava D. Dysregulation of cardiogenesis, cardiac conduction, and cell cycle in mice lacking miR-NA-1-2. Cell. 2007; 129: 303-317.

21. Wang JX, Jiao JQ, Li Q, Long B, Wang K, Liu JP, Li YR, Li PF. miR-499 regulates mitochondrial dynamics by targeting calcineurin and dynamin-related protein-1. Nat Med. 2011; 17: 71-78.

22. Qian L, Van Laake LW, Huang Y, Liu S, Wendland MF, Srivastava D. miR-24 inhibits apotosis and repress Bim in mouse cardiomyocytes. J Exp Med. 2011; 208: 549-560.

23. Li DF, Tian J, Guo X, Huang LM, Xu Y, Wang CC, Wang JF, Ren AJ, Yuan WJ, Lin L. Induction of microRNA-24 by HIF-1 protects against ischemic injury in rat cardiomyocytes. Physiol Res. 2012; 61: 555-565.

24. Du JK, Cong BH, Yu Q, Wang H, Wang L, Wang CN, Tang XL, Lu JQ, Zhu XY, Ni X. Upregulation of miR-22 contributes to mycardial ischemia reperfusion injury by interfering with the mitochondrial function. Free Radic Biol Med. 2016; 96: 406-417.

25. Zeng XC, Li L, Wen H, Bi Q. microRNA128 inhibition attenuates myocardial ischemia/reperfusion injurycardiomyocytes apoptosis by the targeted activaition of peroxisome proliferator-activated receptor gamma. Mol Med Rep. 2016; 14: 129-136.
26. Ke ZP, Xu P, Shi Y, Gao AM. MicroRNA-93 inhibits ischemia reperfusion induced cardiomyocyte apoptosis by targeting PTEN. Oncotarget. 2016; 7: 28796-28805. https:// doi.org/10.18632/oncotarget.8941.

27. Gao CK, Liu H, Cui CJ, Liang ZG, Yao H, Tian Y. Roles of MicroRNA-195 in cardiomyocyte apoptosis induced by myocardial ischemia-reperfusion injury. J Genet. 2016; 95: 99-108.

28. Urbich C, Kuehbacher A, Dimmeler S. Role of microRNAs in vascular diseases, inflammation, and angiogenesis. Cardiovasc Res. 2008; 79: 581-588.

29. Harris TA, Yamakuchi M, Ferlito M, Mendell JT, Lowenstein CJ. MicroRNA-126 regulates endothelial expression of vascular cell adhesion molecule 1. Proc Natl Acad Sci U S A. 2008; 105: 1516-1521.

30. Wang S, Aurora AB, Johnson BA, Qi X, McAnally J, Hill JA, Richardson JA, Bassel-Duby R, Olson EN. The endothelial specific microRNA microRNA-126a-5p governs vascular integrity and angiogenesis. Dev Cell. 2008; 15: 261-271.

31. Fish JE, Santoro MM, Morton SU, Yu S, Yeh RF, Wythe JD, Ivey KN, Bruneau BG, Stainier DY, Srivastava D. microRNA-126a-5p regulates angiogenic signaling and vascular integrity. Dev Cell. 2008; 15: 272-284.

32. Kuhnert F, Mancuso MR, Hampton J, Stankunas K, Asano T, Chen CZ, Kuo CJ. Attribution of vascular phenotypes of the murine Egfl7 locus to the microRNA microRNA126-5p. Development. 2008; 135: 3989-3993.

33. Zernecke A, Bidzhekov K, Noels H, Shagdarsuren E, Gan L, Denecke B, Hristov M, Koppel T, Jahantigh MN, Lutgens E, Wang S, Olson EN, Schober A, Weber C. Delivery of microRNA-126 by apoptotic bodies induces CXCL12-dependent vascular protection. Sci Signal. 2009; 2: ra81.

34. van Solingen C, Seghers L, Bijkerk R, Duijs JM, Roeten MK, van Oeveren-Rietdijk AM, Baelde HJ, Monge M, Vos JB, de Boer HC, Quax PH, Rabelink TJ, van Zonneveld AJ. Antagomir-mediated silencing of endothelial cell specific microRNA-126 impairs ischemia-induced angiogenesis. J Cell Mol Med. 2009; 13: 1577-1585.

35. Tang R, Pei L, Bai T, Wang J. Down-regulation of microRNA-126a-5p contributes to overexpression of VEGFA in lipopolysaccharide-induced acute lung injury. Biotechnol Lett. 2016; 38: 1277-1284.

36. Depre C, Kim SJ, John AS, Huang Y, Rimoldi OE, Pepper JR, Dreyfus GD, Gaussin V, Pennell DJ, Vatner DE, Camici PG, Vatner SF. Program of cell survival underlying human and experimental hibernating myocardium. Circ Res. 2004; 95: 433-440.

37. Sugiyama Y, Suzuki A, Kishikawa M, Akutsu R, Hirose T, Waye MM, Tsui SK, Yoshida S, Ohno S. Muscle develops a specific form of small heat shock protein complex composed of MKBP/HSPB2 and HSPB3 during myogenic differentiation. J Biol Chem. 2000; 275: 1095-1104. 
38. Depre C, Wang L, Sui X, Qiu H, Hong C, Hedhli N, Ginion A, Shah A, Pelat M, Bertrand L, Wagner T, Gaussin V, Vatner SF. H11 kinase prevents myocardial infarction by preemptive conditioning of the heart. Circ Res. 2006; 98: 280-288.

39. Yuan Y, Pan S, Yang SL, Liu YL, Xu QM. Antioxidant and cardioprotective effects of Ilex cornuta on myocardial ischemia injury. Chin J Nat Med. 2017; 15: 94-104.
40. Jiang B, Liang P, Wang K, Lv C, Sun L, Tong Z, Liu Y, Xiao X. Nucleolin involved in myocardial ischaemic preconditioning via post-transcriptional control of HSPA1A expression. Cardiovasc Res. 2014; 102: 56-67.

41. Jiang B, Zhang B, Liang P, Chen G, Zhou B, Lv C, Tu $\mathrm{Z}$, Xiao X. Nucleolin protects the heart from ischaemiareperfusion injury by up-regulating heat shock protein 32 . Cardiovasc Res. 2013; 99: 92-101. 